\title{
\#ME TOO MOVEMENT: INFLUENCE OF SOCIAL MEDIA ENGAGEMENT ON INTENTION TO CONTROL SEXUAL HARASSMENT AGAINST WOMEN
}

\author{
Seema Shukla \\ Research Scholar, School of Humanities, \\ Lovely Professional University, Punjab \\ Pavitar Parkash Singh \\ Professor, Mittal School of Business, \\ Lovely Professional University, Punjab \\ Garima \\ Assistant Professor, School of Management, \\ IMS Unison University, Dehradun
}

\begin{abstract}
Social media provide a common platform to public to speak about social injustice and put grievances about the polices. They also unite and act against crimes. Social Media has been instrumental in the propagation of gender inequality protests around the world. This purpose study is to assess the influence of "\#Me Too movement" on intention to control sexual harassment against women and further to suggest a framework using mass communication as a tool to create awareness and control sexual harassment against women. Multivariate data analysis was conducted though Partial Least Squares Path Modeling (PLS-SEM) to analyze the data. The questionnaire was circulated through WhatsApp and emails to 800 Indian participants. The results suggested that social media movement like "\#Me Too movement" has a positive influence on the intention to control sexual harassment against women. This research showed that awareness about the sex- based crimes could be increased with the participation in these kinds of social movements which in turn leads to formation of intention to control sexual harassment against women.
\end{abstract}

Keywords: Social Media Engagement, \#Me Too Movements, Sexual Harassment.

\section{INTRODUCTION}

With the growth in the numbers of users of social media it has become a mainstream media platform through which the one-third population of the world has been connected (Nelson-Field \& Taylor, 2012). Approximately $50 \%$ of Indian population are assessing social network sites in 2020 and it is predicted that approximately $67.4 \%$ will be able to assess social networks in 2025 (Keelery,2020). The accessibility, affordability and availability of mobile phones have increased individual's interaction with social media sites (Shiva, Narula, Shahi, 2020). The engagement on social media due to the proliferation of social media platforms has been able to significantly influence the perception of public about the reality. It has emerged as a very powerful tool in spreading information (Fauzi et al., 2020, Jain et al., 2020), awareness and mobilizing campaigns on a variety of issues. It has proven its effectiveness in changing the public opinion and attitude towards critical social issues such as crime against women (Gitlin, 2003). The advancements of technology have direct effect on the lives of people (Dwivedi, Narula, 2020).

The \#Me Too, a social media movement has created many headlines in creating awareness and changing attitude of people towards sexual violence against women, this movement has highlighted the issues related to sexual violence against women and made aware the general public about sexism and sexual based crimes. It has also drawn the attention of common public towards the power structures and gender inequalities which are deeply rooted in the patriarchal society. The "\#Me Too movement" is one of the prominence movement happened on social media which deals with sexual violence against women. It has also increased debates and critical discussions on gender discrimination and crimes against women on social media. The mainstream media also witness the same trend (Jaffe, 2018). This movement exposed many high-profile 
personalities in US such as film producer Harvey Weinstein (Mendes et al., 2018). The sex offenders received a huge criticism and legal and organizational action due to this movement (North, 2019; Stone \& Vogelstein, 2019). Nevertheless, the "\#Me Too movement" put sexual harassment into limelight and provided feminism more media coverage and create a huge public interest which was never received earlier (Gill, 2016; Jaffe, 2018).

\section{\#Me Too movement}

Tarana Burake an African American Women Activist understood the power of Social Media and started \# Me Too Movement in 2006 to increase awareness about sexual harassment and sexual assault (Braileanu et al.,2020; Jaffe, 2018; Mendes, Ringrose, \& Keller, 2018). The movement took speed in October 2017 when Alyssa Milano an American Actress posted "\#Me Too" on social media platform 'Twitter' ("Vision," 2018; Zarkov \& Davis, 2018). The actress act increases the popularity of "\#Me Too movement" among victims and it encourage the survivors to share their stories on social media. The movement immediately became global. The "\#Me Too movement" initiated critical and political discussions about the relationship between power and sex (Gill, 2016; Gill \& Orgad, 2018; Jaffe, 2018). The movement revealed that sexual harassment is more about dominance and power than the sexual attraction between the two genders (Jaffe, 2018).Since October 2017 the people of 85 countries participated in the movement (Gill \& Orgad, 2018). Some researchers found that \#Me Too raises consciousness and solidarity.

\section{\# Me Too movement in India}

The "\#Me Too movement" was initiated in 2018 September in India when Tanushree Dutta accused Nana Patekar for his inappropriate behavior on film set of film 'Horn Ok Pleassss' (Roy,2019). Later, a list of females came forward to discuss sexual assault incidents happened to them through "\#Me Too movement". All of them are very famous personalities and keep a very powerful position in Indian Society after the sexual allegations Mr. MJ Akbar has resigned from his post and Sajid Khan must step down from his upcoming big budget venture Housefull part 4. Indian women have shared their painful stories. They have also mentioned the detailed accounts of alleged molestation and sexual harassment done by their former bosses and colleagues (Kazmin, 2018).

\section{Sexual Harassment}

Sexual harassment is gender-based discrimination that mostly target marginal people mostly females in society. It consists of different acts such as sexual comments and inappropriate or unwelcome promises of rewards in exchange for sexual favors. Actions like whistling, staring, requests for dates or unwanted physical conduct and offensive language are considered sexual harassment. The act of asking for sexual favour in exchange for promotion or employment is also considered as the act of sexual harassment at workplace (Jacobson \& Eaton, 2018). The Indian Penal Code has defined sexual harassment in Section 354, which is further divided into sections $\mathrm{A}, \mathrm{B}, \mathrm{C}$ and $\mathrm{D}$. Section $354 \mathrm{~A}$ is dealing with definition and its punishment of sexual harassment. According to this section any physical contact, unwelcome sexual overtures, showing pornography and making sexual remarks are considered as sexual harassment act (Tripathi, 2014). NCRB data revealed that crimes against women have increased from 58.8 to 62.4 from 2018 to 2019. There were 32,033 incidents of rape were reported in 2019 (National Crime Records Bureau, 2019)

\section{Females' Engagement on Social Media}

The use of internet and social networks for political or social engagement has attracted researchers' attention in the past decades (Schuster, 2013). Discussions approach how online activism could reach the real world (Livingstone et al., 2005), other even points that Facebook accounts have been disregarded when it comes to political participation (Christensen, 2011; Schuster, 2013). While several researches suggest many ways on how social media can impact on collective action (Valenzuela, 2013), few has dedicated efforts to understand females' behavior regarding protests participation (Loiseau \& Nowacka, 2015; Schuster, 2017). Social media has proved itself as a powerful tool to bring females' interests and rights to public knowledge (Kapoor et al., 2017). The unprecedented use of social media by women represents an important step to bring opportunities and several discussions regarding (in)equality, gender gap, among others into media 
attention (Loiseau \& Nowacka, 2015).Easy access and low in cost, online participation in protests is a preference for many young women, especially the ones who lack of resources, furthermore, this option enables a choice regarding how much of their identity will be exposed (Schuster, 2013).In Brazil, political movements in 2013 were marked by a strong online engagement and participation, which brought a different way of making protests in the country (Queiroz, 2017).

Regarding females' participation on online activism, the literature points to a wave of feminist forces trying to direct efforts into transforming online social movements into actual change: The Feminist fourth wave. This new wave would be marked by the intense use of social media as important vectors of change (Hollanda, 2018). Accordingly, it is within the online environment where women organize themselves and take a stand against abuse, gender discrimination, by developing a support network, where it is possible to share stories and testimonials, and also organizing campaigns, social actions and protests. Differently from previous decades, the internet and social media enable a much broader capability of information dissemination, where people could get information and also debate their ideas (Moraes, Consolmagno \& Pinheiro, 2020).On the other hand, previous research on females' behavior towards political engagement points to evidence that women engage in less visible political behaviors on social media because they are more likely to use social media for relationship maintenance and seem to be able to overcome political confrontations and exposure (Bode,2016).

However, many experts showed their concerns about the impact of \#MeToo movement on common public but they argued that the movement has increased the battle between both genders which raised women against men (Kunst, Bailey, Prendergast, \& Gundersen, 2019). Burstein \& Linton (2002) argued that social movements could worked as revolution and brought change in the society by exerting influence on the huge number of public (Burstein \& Linton, 2002). However, the motives of most research studies were to study how the social movements mobilize people to act, but there is a scarcity of the study which discussed about the impact of social movements on the broader public (Louis, 2009). This research study also discussed about the influence of joint effort of common public could create the centerpiece for example Teixeira, Spears, \& Yzerbyt, in 2019. There are many research have been done to study the influence and impact of \# Me Too movement on global arena but still the study about the influence of \# Me Too movement in Indian context is missing. The purpose of present research study is to fill that gap by critically examine the influence of "\#Me Too movement" on intention to control sexual harassment incidents against women.

\section{LITERATURE REVIEW}

Social media engagement is interpreted as the measurement of individual's involvement with social media. It also refers to 'individual attitude towards the relationship with social media use' (Xiaoli, 2020). Engagement is a complex structure, which consist behavior, cognition, and affection. (Hollebeek ,2011; Myers,1993).

Hence, the present study aims to achieve the following objectives: The first objective of the study is to assess the influence of "\#Me Too movement" on intention to control sexual harassment against women. The second objective of the study is to suggest a framework using mass communication as a tool to create awareness and control sexual harassment against women.

To develop a framework using "\#Me Too movement" as a tool to create awareness and control sexual harassment incidents, the social media engagement sale and the theory of Planned Behavior were used. Affective engagement, behavioral engagement and cognitive engagement construct were used to measure social media engagement of individuals.

Hollander in (2018) stated in her research paper that the reporting could be a good tool to reduce the number of victimizations of Sexual Violence. Caputi et al., (2019) have discussed in their study that \#Me Too movement has encouraged considerable interest in not only sex-based crimes, but also stimulated the actionable outcomes such as reporting and prevention.

It is acknowledging the existence of other influential factors on the use of social 
networks and protests' participations online, however, the hypotheses presented in this paper show a broader relationship to the chosen object of study. As the present research study aims to assess the influence of "\#Me Too movement" the following hypothesis were formulated:

$\mathrm{H}_{1}$ : Social Media engagement creates awareness about sexual harassment against women.

$\mathrm{H}_{2}$ : Awareness about sexual harassment against women influences attitude towards control of sexual harassment against women.

$\mathrm{H}_{3}$ : Awareness about sexual harassment against women influences subjective norms towards control of sexual harassment against women.

$\mathrm{H}_{4}$ : Awareness about sexual harassment against women influences perceived behavioral control towards control of sexual harassment against women.

To assess an individual intention towards control of sexual harassment against women the three constructs of theory of planned behavior were used. The Theory of Planned Behavior (TPB) was developed as an extension of TRA, adding the perceived behavioral control construct, which influences both intention and behavior (Ajzen, 1991). The relative importance of attitude, subjective norm, and perceived behavioral control in predicting intention fluctuate according to the different situations to which the theory is applied. According to TPB, human behavior is based on behavioral beliefs, that is the possible consequences of human behavior leading to $a$ favorable or unfavorable behavioral attitude, on normative beliefs, which would be the social pressure on behavior, and also on beliefs about control, referring to factors that can facilitate or impede the performance of the individual's behavior (Ajzen, 1991).

The attitude towards control of Sexual Harassment against women is measured with the reporting of sexual harassment. The Subjective norms towards control of sexual harassment against women was considered as reporting of sexual harassment against women. To measure the sexual harassment awareness construct eight items of sexual harassment myth were used. In this research control of sexual harassment is refers as the restriction of an activity of sexual harassment which is further defined with two variables reporting of sexual harassment incidents (Caputi et al., 2019). To assess the influence of "\#Me Too movement" on intention to control sexual harassment against women following hypothesis were formed:

$\mathrm{H}_{5}$ : Attitude towards control of sexual harassment against women influence intention to control sexual harassment against women.

$\mathrm{H}_{6}$ : Subjective norms towards control of sexual harassment against women influence intention to control sexual harassment against women.

$\mathrm{H}_{7}$ : Perceived behavioral control towards control of sexual harassment against women influence intention to control sexual harassment against women.

The relationship has been displayed through structural model in figure 1.

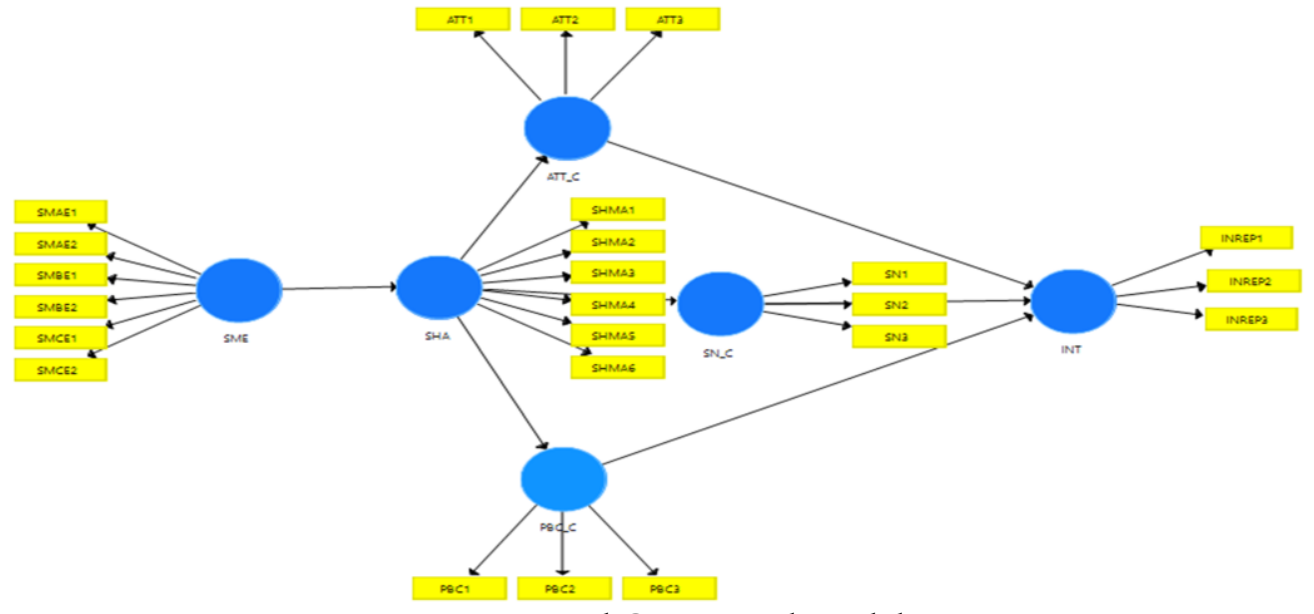

Figure 1: Proposed Conceptual Model 


\section{RESEARCH METHODOLOGY}

Quantitative methodology (Multivariate data analysis) was used to accomplish the research objectives. The theories on social movements (movements against sexual harassment) on social media are less developed, therefore partial least squares path modeling (PLS-SEM) was used to validate the proposed model (Hair et al., 2017). The initial questionnaire was evaluated by a group of 6 specialists in Mass Communication, who had already worked in the area of sexual violence. The responses of ten respondents were used do the pilot study. Very limited changes were incorporated as per the satisfactory feedback received from the respondents. Standards scales were adapted from previous studies.

Data was collected through an online survey through snowball sampling. The questionnaire was circulated through WhatsApp and emails to 800 participants. G*Power software 3.1.9.7 version was used to estimate the minimum required sample size (Faul et al., 2009). At $a=5 \%$ (level of significance), with statistical power of 0.95 and average effect size $\left(f^{2}=0.15\right)$, the estimated minimum sample size was 89 . As the sample was 220 respondents, it is suitable for estimation by PLS-SEM (see Figure 2).

\section{Assessment of Measurement Model}

Outer model specifications were tested by applying reliability and validity checks for the model. The model's indicators were reflective. As suggested by Hair et al., (2019a, 2019b, 2020), the first step for assessment of the reflective measurement model involves examining the indicator loadings. All the indicator reported acceptable and recommended loadings of above 0.70 (Hair et al., 2019a, 2019b, 2020, Ringle et al, 2020).

The internal consistency of the scale items was established through Cronbach's alpha coefficient (a) and composite reliability. Convergent validity was established through average variance extracted (AVE), accepted value greater than 0.5 (Hair et al., 2017). The discriminant validity was evaluated using the Fornell-Larcker criterion and HTMT (heterotrait-monotrait ratio of correlations) (Hair et al., 2017). Table 1 and 2 presents these values; all the indicators mentioned and shows that all values are within the limits established by the authors.

Henseler et al. (2015) proposed the heterotraitmonotrait (HTMT) ratio of the correlations (Voorhees et al., 2016). The HTMT is defined as "the mean value of the item correlations

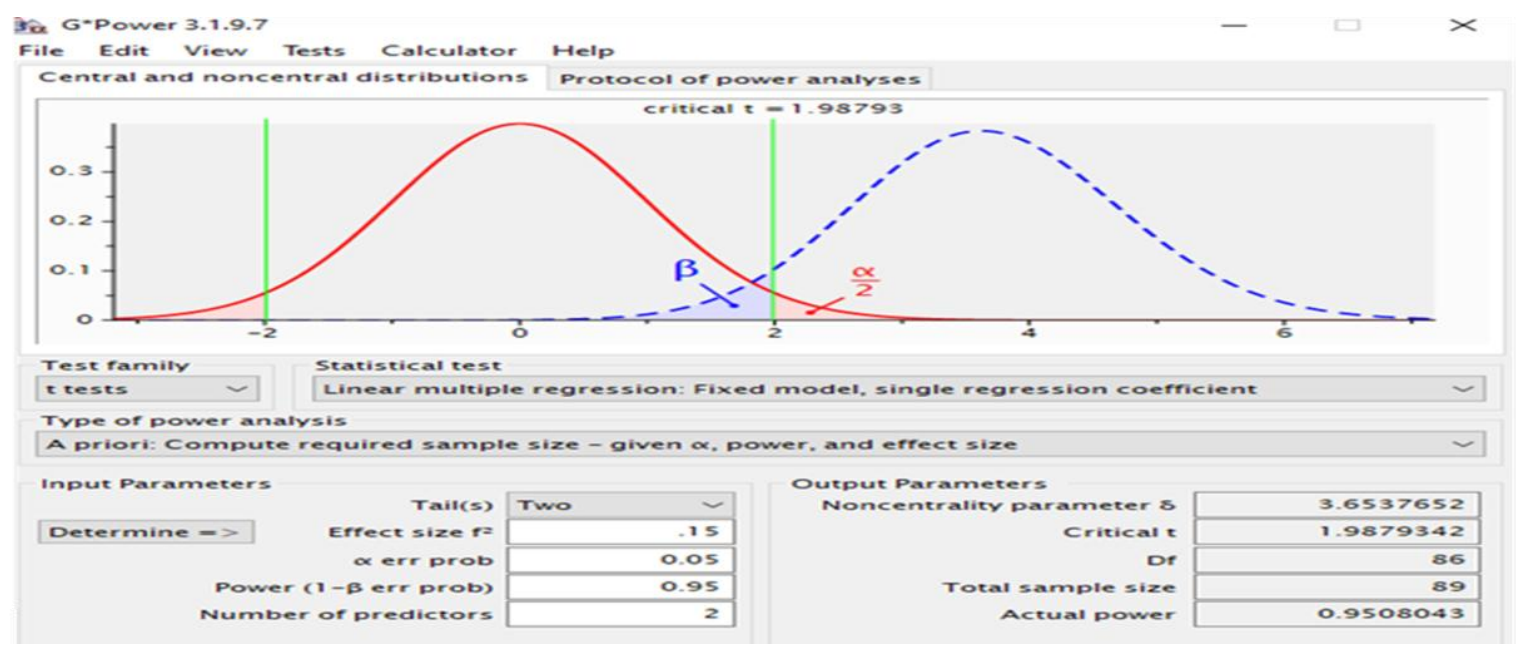

Figure 2: Sample size estimation through G*Power software (3.1.9.7 version).

\section{RESULTS}

Among the total respondents $62 \%$ were females and $37 \%$ were male respondents. Most respondents were young, aged between 18 and 22 years old $(57.3 \%), 29.5 \%$ were 23 and 27 years old and the remaining $13 \%$ were over 28 years old. across constructs relative to the (geometric) mean of the average correlations for the items measuring the same construct".

Higher HTMT values indicates a problem of discriminant validity. Henseler et al. (2015) propose a threshold value of 0.90 for conceptually similar structural models. In such 
a setting, higher HTMT value (above 0.90) would indicates that discriminant validity problem is not present. In the present study, all the values were below the threshold of .90 thereby establishing the uniqueness of all the constructs as per the empirical standards as represented in Table 3.

Table 1: Measurement Model Accuracy Assessment.

\begin{tabular}{|c|c|c|c|c|c|c|}
\hline Research Constructs & $\begin{array}{l}\text { PLS Code } \\
\text { Items }\end{array}$ & $\begin{array}{c}\text { Outer } \\
\text { loadings }\end{array}$ & $\begin{array}{l}\text { Cronbac's } \\
\text { Alpha (a) }\end{array}$ & rhoA & $\begin{array}{l}\text { Composite } \\
\text { Reliability }\end{array}$ & AVE \\
\hline \multirow[t]{6}{*}{ Social Media Engagement } & SME1 & 0.682 & \multirow{6}{*}{0.858} & \multirow{6}{*}{0.922} & \multirow{6}{*}{0.870} & \multirow{6}{*}{0.531} \\
\hline & SME2 & 0.688 & & & & \\
\hline & SME3 & 0.649 & & & & \\
\hline & SME4 & 0.600 & & & & \\
\hline & SME5 & 0.857 & & & & \\
\hline & SME6 & 0.856 & & & & \\
\hline \multirow{4}{*}{$\begin{array}{l}\text { Sexual Harassment } \\
\text { Awareness }\end{array}$} & SHA2 & 0.813 & \multirow{4}{*}{0.813} & \multirow{4}{*}{0.833} & \multirow{4}{*}{0.876} & \multirow{4}{*}{0.639} \\
\hline & SHA3 & 0.702 & & & & \\
\hline & SHA4 & 0.835 & & & & \\
\hline & SHA5 & 0.840 & & & & \\
\hline \multirow{3}{*}{$\begin{array}{l}\text { Attitude towards control of } \\
\text { sexual harassment against } \\
\text { women. }\end{array}$} & ATT1 & 0.836 & \multirow{3}{*}{0.752} & \multirow{3}{*}{0.763} & \multirow{3}{*}{0.857} & \multirow{3}{*}{0.666} \\
\hline & ATT2 & 0.781 & & & & \\
\hline & ATT3 & 0.831 & & & & \\
\hline \multirow{3}{*}{$\begin{array}{l}\text { Subjective norms towards } \\
\text { control of sexual harassment } \\
\text { against women. }\end{array}$} & SN1 & 0.870 & \multirow{3}{*}{0.894} & \multirow{3}{*}{0.901} & \multirow{3}{*}{0.934} & \multirow{3}{*}{0.825} \\
\hline & SN2 & 0.945 & & & & \\
\hline & SN3 & 0.909 & & & & \\
\hline \multirow{3}{*}{$\begin{array}{l}\text { Perceived behavioral control } \\
\text { towards control of sexual } \\
\text { harassment against women. }\end{array}$} & PBC1 & 0.913 & \multirow{3}{*}{0.875} & \multirow{3}{*}{0.883} & \multirow{3}{*}{0.923} & \multirow{3}{*}{0.800} \\
\hline & PBC2 & 0.910 & & & & \\
\hline & PBC3 & 0.859 & & & & \\
\hline \multirow{3}{*}{$\begin{array}{l}\text { Intention to control sexual } \\
\text { harassment against women. }\end{array}$} & INREP1 & 0.903 & \multirow{3}{*}{0.903} & \multirow{3}{*}{0.916} & \multirow{3}{*}{0.939} & \multirow{3}{*}{0.838} \\
\hline & INREP2 & 0.942 & & & & \\
\hline & INREP3 & 0.900 & & & & \\
\hline
\end{tabular}

Note: Low outer loadings were reported for SHA1 and SHA6, hence they were deleted from analysis.

Source: Authors' Calculation

Table 2: Fornell-Larcker Criterion (Discriminant Validity Assessments)

\begin{tabular}{|l|c|c|c|c|c|c|}
\hline & ATT_C & INT & PBC_C & SHA & SME & SN_C \\
\hline ATT_C & 0.816 & & & & & \\
\hline INT & 0.375 & 0.915 & & & & \\
\hline PBC_C & -0.195 & -0.124 & 0.894 & & & \\
\hline SHA & -0.376 & -0.274 & 0.216 & 0.799 & & \\
\hline SME & -0.124 & -0.026 & 0.122 & 0.202 & 0.729 & \\
\hline SN_C & 0.423 & 0.405 & -0.134 & -0.322 & -0.084 & 0.909 \\
\hline
\end{tabular}

Source: Authors' Calculation

Table 3: HTMT Ratio of Correlations (Discriminant Validity Assessments)

\begin{tabular}{|l|c|c|c|c|c|c|}
\hline & ATT_C & INT & PBC_C & SHA & SME & SN_C \\
\hline ATT_C & & & & & & \\
\hline INT & 0.435 & & & & & \\
\hline PBC_C & 0.237 & 0.130 & & & & \\
\hline SHA & 0.476 & 0.304 & 0.242 & & & \\
\hline SME & 0.187 & 0.049 & 0.123 & 0.182 & & \\
\hline SN_C & 0.503 & 0.448 & 0.150 & 0.363 & 0.101 & \\
\hline
\end{tabular}

Source: Authors' Calculation 


\section{Structural Model Assessments}

Satisfactory results from the measurement model assessment leads to assessment of structural model. Standard assessment criteria, as suggested by Hair et al., (2020) which include the coefficient of determination $\left(\mathrm{R}^{2}\right)$, effect size $\left(\mathrm{f}^{2}\right)$, the statistical significance and relevance of the path coefficients and the blindfolding-based cross validated redundancy measure $\mathrm{Q}^{2}$ were computed for the assessment of structural model. Bootstrapping process with recommended 5000 bootstraps were conducted to compute the relevant $\mathrm{p}$ values.

Collinearity was examined through VIF values which were found to be below recommended value of 5 (Hair et al., 2017). The inner VIFs were found to be below the threshold limits with social media engagement (1), sexual awareness about sexual harassment against women (1), attitude towards control of sexual harassment against women (1.247), subjective norms towards control of sexual harassment against women (1.22), and perceived behavioral control towards control of sexual harassment (1.043) Hence, collinearity issues were not reported in the study (Hair et al., 2017).

In the present study intention to control sexual harassment against women are significantly determined by attitude, subjective norms, and perceived behavioral control towards control of sexual harassment. The results are reported in Table 4.

Table 4: Predictive Relevance of the Path Model Assessments Results

\begin{tabular}{|l|c|c|}
\hline Constructs & R $^{\mathbf{2}}$ values & $\begin{array}{c}\text { Adjusted R } \\
\text { values }\end{array}$ \\
\hline ATT_C & 0.141 & 0.137 \\
\hline INT & 0.216 & 0.205 \\
\hline PBC_C & 0.047 & 0.042 \\
\hline SHA & 0.041 & 0.036 \\
\hline SN_C & 0.103 & 0.099 \\
\hline
\end{tabular}

Source: Authors' Calculations

The study reported SRMR value of 0.073 in the structural model. This value is fairly below the threshold value of 0.08 , hence this indicates that the model had a good explanatory power (Henseler et al., 2016). The results for structural model assessment and hypotheses testing are reported in Table 5.

\begin{tabular}{|l|l|l|l|l|l|}
\hline \multicolumn{6}{|c|}{ Table 5: Structural Model Assessments } \\
Results \\
\hline $\begin{array}{l}\text { Hypot } \\
\text { hesis }\end{array}$ & $\begin{array}{l}\text { Path } \\
\text { Relatio } \\
\text { nship }\end{array}$ & $\begin{array}{l}\text { Path } \\
\text { Coeffi } \\
\text { cient }\end{array}$ & $\begin{array}{l}\text { Sa } \\
\text { mpl } \\
\text { e } \\
\text { Me } \\
\text { an } \\
\text { (M) }\end{array}$ & $\begin{array}{l}\text { t- } \\
\text { val } \\
\text { ues }\end{array}$ & $\begin{array}{l}\text { Decis } \\
\text { ions }\end{array}$ \\
\hline $\mathrm{H}_{1}$ & $\begin{array}{l}\text { SME> } \\
\text { >SHA }\end{array}$ & .202 & .230 & $\begin{array}{l}2.35 \\
9^{* *}\end{array}$ & $\begin{array}{l}\text { Supp } \\
\text { orted }\end{array}$ \\
\hline $\mathrm{H}_{2}$ & $\begin{array}{l}\text { SHA }> \\
>\text { ATT }\end{array}$ & .376 & .381 & $\begin{array}{l}5.20 \\
1^{* * *}\end{array}$ & $\begin{array}{l}\text { Supp } \\
\text { orted }\end{array}$ \\
\hline $\mathrm{H}_{3}$ & $\begin{array}{l}\text { SHA }> \\
>\text { SN }\end{array}$ & .322 & .326 & $\begin{array}{l}5.14 \\
8^{* * *}\end{array}$ & $\begin{array}{l}\text { Supp } \\
\text { orted }\end{array}$ \\
\hline $\mathrm{H}_{4}$ & $\begin{array}{l}\text { SHA> } \\
\text { >PBC }\end{array}$ & .216 & .222 & $\begin{array}{l}3.68 \\
* *\end{array}$ & $\begin{array}{l}\text { Supp } \\
\text { orted }\end{array}$ \\
\hline $\mathrm{H}_{5}$ & $\begin{array}{l}\text { ATT> } \\
\text { >INT }\end{array}$ & .242 & 0.25 & 3.64 & $\begin{array}{l}\text { Supp } \\
\text { orted }\end{array}$ \\
\hline $\mathrm{H}_{6}$ & $\begin{array}{l}\text { SN>>I } \\
\text { NT }\end{array}$ & .298 & .298 & $\begin{array}{l}4.08 \\
4^{* * *}\end{array}$ & $\begin{array}{l}\text { Supp } \\
\text { orted }\end{array}$ \\
\hline $\mathrm{H}_{7}$ & $\begin{array}{l}\text { PBC>> } \\
\text { INT }\end{array}$ & -.037 & .036 & .551 & $\begin{array}{l}\text { Not } \\
\text { Supp } \\
\text { orted }\end{array}$ \\
\hline
\end{tabular}

Source: Authors' Calculations; Path Coefficient $\left({ }^{*} p<0.01,{ }^{* *} p<0.05,{ }^{* * *} p<0.001\right)$

The results vindicated that subjective norms towards control of sexual harassment most prominent feature which influence intention to control sexual harassment against women $(\beta=$ $0.242 \mathrm{p}<0.001)$, thereby supporting H6. Although significant positive relationship was found between social media engagement and creating awareness about sexual harassment, which was visible as per the huge response and wide protest offered through \#Me Too movement. Significant positive relationship reported for attitude towards control of sexual harassment against women, subjective norms towards control of sexual harassment against women and perceived behavioral control towards control of sexual harassment against women confirms that sexual harassment awareness which was created through participating or engaging in protest movement such as "\#Me Too movement" through social media platforms does influence prominent antecedents of intention (See figure 3).

PLS path model's predictive accuracy was assessed and established through $\mathrm{f}^{2}$ effect sizes (Cohen, 1988) and $\mathrm{Q}^{2}$ value (Geisser, 1974; Stone, 1974). The results of $\mathrm{f}^{2}$ effect sizes and $\mathrm{Q}^{2}$ are reported in Table 6. Further, the goodness of fit criterion was investigated by 
the standardized root mean square residual (SRMR) global fit indices. control of Sexual Harassment against women. The Subjective norms towards control of

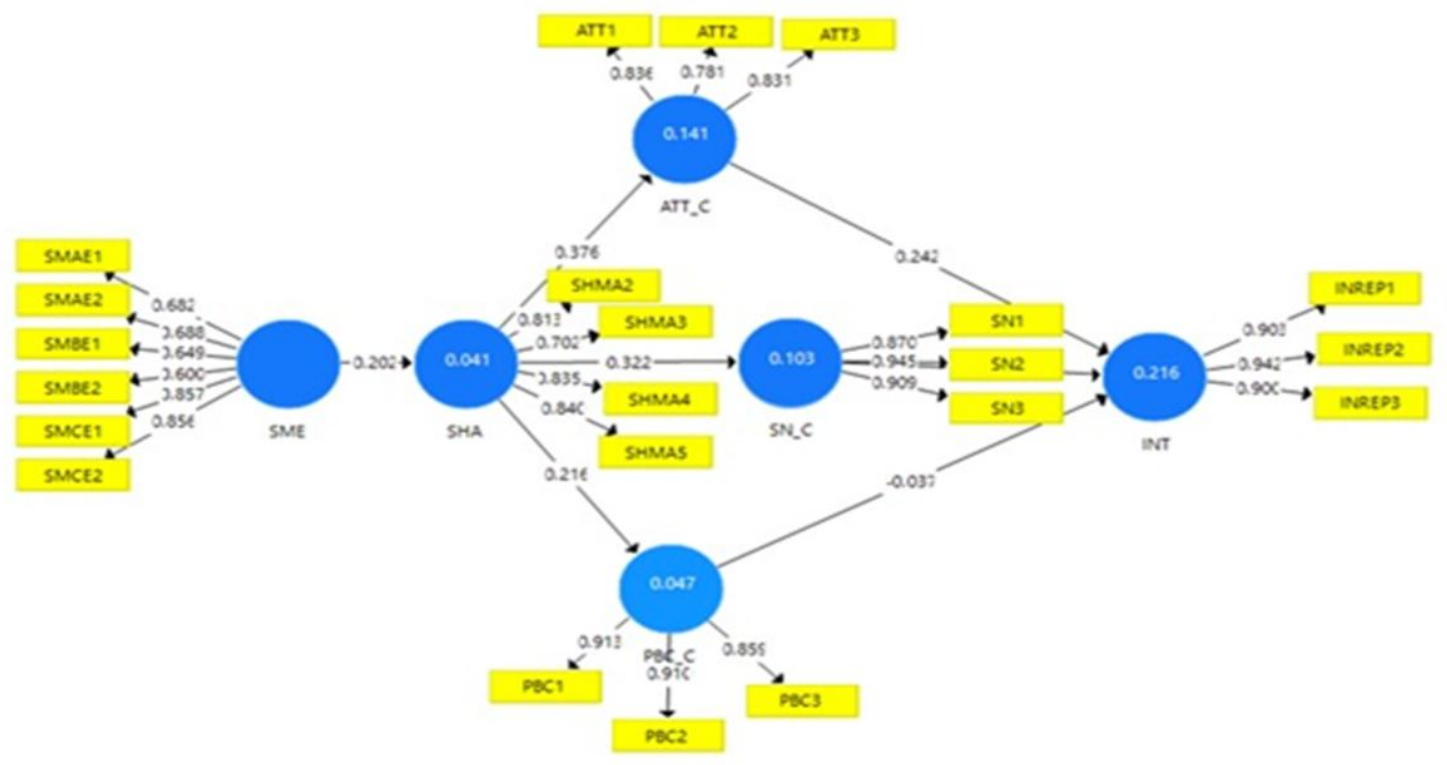

Figure 3: Structural Model Assessment Results

Table 6: Predictive Relevance of the Path Model Assessments through $\mathrm{f}^{2}$ effect sizes and $\mathrm{Q}^{2}$

\begin{tabular}{|l|l|l|l|l|l|l|c|}
\hline \multicolumn{7}{|c|}{$\mathbf{f}^{2}$ effect sizes values } & $\mathbf{Q}^{\mathbf{2}}$ \\
\hline & ATT_C & INT & PBC_C & SHA & SME & SN_C & Q $^{2}$-SSE/SSO \\
\hline ATT_C & & 0.060 & & & & & .088 \\
\hline INT & & & & & & & .168 \\
\hline PBC_C & & $\mathbf{0 . 0 0 2}$ & & & & & .031 \\
\hline SHA & $\mathbf{0 . 1 6 4}$ & & 0.049 & & & 0.115 & .022 \\
\hline SME & & & & 0.042 & & & NA \\
\hline SN_C & & 0.092 & & & & & .022 \\
\hline
\end{tabular}

Source: Authors' Calculations

\section{DISCUSSION AND IMPLICATIONS}

The result shows that social media engagement is creating awareness about Sexual Harassment against women. It can be seen in the case of \#Me Too movement, the movement has drawn attention towards the issue of gender-based violence such as sexual harassment, rape and sexual abuse. The people spoke about organizational, criminal, and ethical issues related to Sexual Harassment against women. This create a huge awareness about Sexual Harassment against women and people started denying myth about Sexual harassment, which is popular from many years (O'Neil, 2018). The result also indicated that SHA plays a very important role in developing attitude towards
Sexual Harassment against women is also controlled by Sexual Harassment Awareness against women. The result is validating that if an individual aware about Sexual Harassment against women, the individual does not bother about the social construction and thinking of peer group. The research study showed that SHA against women has very less influence on the perceived behavioral control towards control of sexual harassment against women. It may be due to the eco system and circumstances available in Indian society. The individual is not confident enough to report the incident of sexual harassment against women because of fear of victim blaming and ashamed. 
The findings of this research study shown that social media movement like "\#Me Too movement" has positive influence on the intention to control sexual harassment against women. This research shows that awareness of sexual crimes against women can be increased and the participation in these kinds of social movements a sexual harassment intention could be controlled. Hence the conceptual model/framework as suggested in the present study vindicates that mass communication such as \#Me Too movement is able to create awareness among the common public, however the authors constructed framework for sexual harassment against women through mass communication was not able with certainty as PBC reported negative relationship with intention.

Though the influence of sexual harassment awareness through mass communication has established with Attitude towards control of sexual harassment against women, Subjective norms towards control of sexual harassment against women and Perceived behavioral control towards control of sexual harassment against women.

\section{Theoretical implications}

The purpose of present research study was to examine the influence of social media movement ("\#Me Too movement") on individual intention to control sexual harassment incidents against women. The research shown that the social media engagement is successful in generating awareness about sexual harassment against women and sexual harassment awareness plays a very important role in developing attitude towards control of sexual harassment against women. Hence, in accordance to the theory of planned behavior, the above implications were drawn and vindicated.

\section{Managerial implications}

The findings indicated that the awareness about sexual harassment against women has increased with the involvement with social media engagement and it awareness about sexual harassment has developed the attitude to control of sexual harassment against women. The government and Nongovernment organization could run this kinds of social media campaigns to create sexual harassment awareness and which leads the attitude to control sexual harassment against women.

\section{LIMITATIONS AND FUTURE RESEARCH DIRECTIONS}

A considerable limitation of our study is that we are not able to establish with certainty that social media engagement with respect to \#Me Too strongly influenced intention to control sexual harassment. However, constructs of theory of planned behavior (TPB) such as attitudes, subjective norms, and perceived behavior control that we tested, were significantly influenced by sexual harassment awareness, which in turn was influenced by social media engagement. Among the other potential limitations of the study are paucity of time, availability of funds, self-reporting biasness and representativeness of the sample were also there.

As the Sexual harassment is a flagrant crime against women and it is increasing day by day in several parts of world. The social media movement like \#Me Too movement has shown a positive relationship in controlling Sexual harassment. The future research could be done on this area by modified questionnaire and taking a larger sample, size.

\section{REFERENCES}

Ajzen, I. (1991). The theory of planned behaviour. Organizational Behavior and Human Decision Processes, 50(2), 179-211. https://doi.org/10.1016/07495978(91)90020-t.

Bode, L. (2016). Closing the gap: gender parity in political engagement on social media. Information, Communication $\mathcal{E}$ Society, 20(4), 587-603. https:// doi.org/10.1080/1369 118x.2016.1202302.

Braileanu, M., Edney, E., Azar, S., Lazarow, F., Mogensen, M. A., Tuburan, S., Kadom, N., \& Phalke, V. (2020). Radiology, sexual harassment, and the \#MeToo movement. Academic Radiology. https://doi.org/10.1016/j.acra.2020.04.0 36

Burstein, P., \& Linton, A. (2002). The impact of political parties, interest groups, and social movement organizations on public policy: some recent evidence and theoretical concerns. Social Forces, 81(2), 
380-408. https://doi.org/10.1353/sof. 2003.0004.

Caputi, T. L., Nobles, A. L., \& Ayers, J. W. (2019). Internet searches for sexual harassment and assault, reporting, and training since the \#MeToo movement. JAMA Internal Medicine, 179(2), 258259.https://doi.org/10.1001/jamain ternmed.2018.5094.

Christensen, H. S. (2011). Political activities on the internet: <em>Slacktivism</em> or political participation by other means? First Monday, 16(2). https://doi.org/ 10.5210/fm.v16i2.3336

PTI (2020, January).

Conviction rate for rape only $27.2 \%$ even as country celebrates justice in nirbhaya case. The Economic Times. Retrieved November 19, 2020, from https://economictimes.indiatimes.com/ news/politics-and-nation/convictionrate-for-rape-only-27-2-even-as-countrycelebrates-justice-in-nirbhayacase/articleshow/73169787.cms?from= mdr

Cohen, J. (1988). Statistical power analysis for the behavioral sciences (2nd ed.). L. Erlbaum Associates. United States of America.

Diamantopoulos, A. (2008). Formative indicators: introduction to the special issue. Journal of Business Research, 61(12), 1201-1202. https://doi.org/10. 1016/j.jbusres.2008.01.008.

Elliott, M., Browne, K., \& Kilcoyne, J. (1995). Child sexual abuse prevention: what offenders tell us. Child Abuse \& Neglect, 19(5), 579-594. https://doi. org/10.1016/0145-2134(95)00017-3.

Faul, F., Erdfelder, E., Buchner, A., \& Lang, A. G. (2009). Statistical power analyses using $G^{*}$ Power 3.1: Tests for correlation and regression analyses. Behavior research methods, 41(4), 1149-1160.

Geisser, S. (1974). A predictive approach to the random effect model. Biometrika, 61(1), 101-107. doi:10.2307/2334290

Gill, R. (2016). Post-postfeminist? new feminist visibilities in postfeminist times. Feminist Media Studies, 16(4), 610-630. https://doi.org/10.1080/14680777.2016. 1193293.

Gill, R., \& Orgad, S. (2018). The shifting terrain of sex and power: From the 'sexualization of culture' to \#MeToo. Sexualities, 21(8), 1313-1324. https:// doi.org/10.1177/13634607 18794647.

Gitlin, T. (2003). The whole world is watching mass media in the making \& unmaking of the New Left. University of California Press. Los Angles.

Hair, J. F., Ringle, C. M., \& Sarstedt, M. (2011). PLS-SEM: Indeed, a silver bullet. Journal of Marketing Theory and Practice, 19(2), 139-152.

https:// doi.org/10.2753/mtp10696679190202.

Hair, J.F., Hult, G.T.M., Ringle, C.M. and Sarstedt, M. (2017a), A primer on partial least squares structural equation modeling (PLS-SEM), Sage, Thousand Oaks, CA.

Hair, J. F., Risher, J. J., Sarstedt, M., \& Ringle, C. M. (2019a). When to use and how to report the results of PLS-SEM. European Business Review, 31(1), 2-24. https://doi.org/10.1108/ebr-11-20180203.

Hair, J.F., Sarstedt, M., Ringle,C.M. (2019b).Rethinking some of the rethinking of partial least squares. Eur J Mark 53(4),566-584. https://doi.org/ 10.1108/EJM-10-2018-0665

Hair,J.F, Howard,M.C., Nitzl,C. (2020). Assessing measurement model quality in PLS-SEM using confirmatory composite analysis. J Bus Res 109(1),101110. https://doi.org/10.1016/j.jbusres .2019.11.069

Henseler, J., Ringle, C. M., \& Sinkovics, R. R. (2009). The use of partial least squares path modeling in international marketing. Advances in International Marketing,20 277-319. https://doi.org/10.11 08/s 14747979(2009)0000020014

Henseler, J., Ringle, C. M., \& Sarstedt, M. (2014). A new criterion for assessing discriminant validity in variance-based structural equation modeling. Journal of the Academy of Marketing Science, 
43(1),

115-135.

https:/ / doi.org/10.1007/s11747-014-

0403-8.

Henseler, J., Hubona, G., \& Ray, P. A. (2016). Using PLS path modeling in new technology research: updated guidelines. Industrial Management \& Data Systems, 116(1), 2-20. https:/ / doi.org/10.1108/imds-09-20150382.

Hollanda, H. B. de. (2018). Explosão Feminista (1st Editio). Companhia das Letras. Brazil.

Hollander, J. A. (2018). Women's self-defense and sexual assault resistance: The state of the field. Sociology Compass, 12(8), e12597.

https://doi.org/10.1111/soc4.12597.

Hollebeek, L. (2011). Exploring customer brand engagement: definition and themes. Journal of Strategic Marketing, 19(7), 555-573. doi: 10.1080/0965254X.2011.599493

Jacobson, R. K., \& Eaton, A. A. (2018). How organizational policies influence bystander likelihood of reporting moderate and severe sexual harassment at work. Employee Responsibilities and Rights Journal, 30(1), 37-62. https:/ / doi.org/10.1007/s10672-0179309-1.

Jain, V. K. et al. (2020). Social media and green consumption behavior of millennials, Journal of Content, Community and Communication, 11(10), 32-51

Jaffe, S. (2018). The Collective Power of \#MeToo. Dissent, 65(2), 80-87.

Kapoor, K. K., Tamilmani, K., Rana, N. P., Patil, P., Dwivedi, Y. K., \& Nerur, S. (2017). Advances in Social Media Research: Past, Present and Future. Information Systems Frontiers, 20(3), 531-558.

https://doi.org/10.1007/s10796-0179810-y.

Kazmin, A. (2018, October 22). This \#MeToo moment looks like a turning point for India. Retrieved November 18, 2020, from

https://www.ft.com/content/4b3c4e7ad2cf-11e8-a9f2-7574db66bcd5
Keelery,S.(2020,October)India - social network penetration 2017-2023 | Retrieved November 18, 2020, from https://www.statista.com/statistics/ 24 0960/share-of-indian-population-usingsocial-networks

Kunst, J. R., Bailey, A., Prendergast, C., \& Gundersen, A. (2018). Sexism, rape myths and feminist identification explain gender differences in attitudes toward the \#metoo social media campaign in two countries. Media Psychology, 22(5), 818-843. https://doi.org/10.1080 /15213269.2018.1532300.

Livingstone, S., Bober, M., \& Helsper, E. J. (2005). Active participation or just more information? Information, Communication \& Society, 8(3), 287-314. https://doi.org/10.1080/ 13691180500259103.

Loiseau, E., \& Nowacka, K. (2015). Can social media effectively include women's voices in decision-making processes? Retrieved November 18, 2020, from http://www.oecd.org/dev/ development-gender/DEVsocialmediaissuespaper-March2015.pdf

Meighan Stone, \& Vogelstein, R. (2019, March). Celebrating \#MeToo's Global Impact. Foreign Policy; Foreign Policy. Retrieved November 18, 2020, from https://foreignpolicy.com/2019/03/07 /metooglobalimpact internationalwomens-day/

Mendes, K., Ringrose, J., \& Keller, J. (2018). \#MeToo and the promise and pitfalls of challenging rape culture through digital feminist activism. European Journal of Women's Studies, 25(2), 236-246. https://doi.org/10.1177/1350506818765 318.

Moraes, G., Consolmagno, G., \& Pinheiro, G. (2020). Social media and protests engagement: what's gender got to do with it? Journal of Content, Community \& Communication, 11(6), 22-31. doi:10.31620/JCCC.6.20/03.

Myers, D. G. (1993). Social Psychology (4 th ed.) McGraw-Hill. New York.

National Crime Records Bureau, GOI. (2019). Crime in India 2019. 1, 1-1298, Rep.). 
Mahipalpur, New Delhi. https://ncrb.gov.in/sites/default/files/ CII\% 202019\%20Volume \%201.pdf

Ni, X., Shao, X., Geng, Y., Qu, R., Niu, G., \& Wang, Y. (2020). Development of the social media engagement scale for adolescents. Frontiers in Psychology, 11. https://doi.org/

10.3389/fpsyg.2020.00701.

North, A. (2019, October). \#MeToo movement: These 7 facts show its impact. Vox; Vox. Retrieved November 18, 2020, https://www.vox.com/identities/2019 /10/4/20852639/ me-too-movementsexual-harassment-law-2019.

O'Neil, A., Sojo, V., Fileborn, B., Scovelle, A. J., \& Milner, A. (2018). The \#MeToo movement: an opportunity in public health? The Lancet, 391(10140), 25872589.https://doi.org/10.1016/ s01406736(18)30991-7.

Queiroz, E. de F. C. (2017). Ciberativismo: a nova ferramenta dos movimentos sociais. Panorama, 7(1), 2. https://doi.org/10.18224/pan.v7i1.5574

Raithel, S., Sarstedt, M., Scharf, S., \& Schwaiger, M. (2011). On the value relevance of customer satisfaction. Multiple drivers and multiple markets. Journal of the Academy of Marketing Science, $\quad 40(4)$, 509-525. https://doi.org/10.1007/s11747-0110247-4.

Ringle, C. M., Sarstedt, M., Mitchell, R., \& Gudergan, S. P. (2020). Partial least squares structural equation modeling in HRM research. International Journal of Human Resource Management, 31(12), 1617-1642. doi:10.1080/09585192.2017.1416655

Roy, A. (2019, June). 2018: The Year When \#MeToo Shook India - 2018: The Year of \#MeToo in India. Retrieved November 18, 2020, from https://economictimes.indiatimes. com/magazines/panache/2018-theyear-when-metoo-shook-india/2018the-year-of-metoo-inindia/slideshow/66346583.cms

Schuster, J. (2013). Invisible feminists? social media and young women's political participation. Political Science, 65(1), 824.

https://doi.org/10.1177/0032318713486 474 .

Schuster, J. (2013). Invisible feminists? Social media and young women's political participation. Political Science, 65(1), 824.

https://doi.org/10.1177/0032318713486 474.

Selander, L., \& Jarvenpaa, S. L. (2016). Digital action repertoires and transforming a social movement organization. MIS Quarterly, $\quad 40(2), \quad 331-352$. https://doi.org/10.25300/misq/ 2016/ 40.2.03.

Shiva,A.,Narula,S.,\& Shahi,K.S.(2020) What drives retail investors' investment decisions? evidence from no mobile phone phobia (nomophobia) and investor fear of missing out (I-FOMO). Journal of Content, Community and Communication, 11(10), 220.https://doi.org/10.31620/ jccc.06.20/02

Szekeres, H., Shuman, E., \& Saguy, T. (2020). Views of sexual assault following \#MeToo: the role of gender and individual differences. Personality and Individual Differences, 166(1),110203. https://doi.org/10.1016/j.paid.2020.110 203

Stone, M. (1974). Cross-validatory choice and assessment of statistical predictions. Journal of the Royal Statistical Society.Series B (Methodological), 36(2), 111-147. Retrieved November 19, 2020, from

http://www.jstor.org/stable/2984809.

Taylor, J. (2012, May) Facebook fans: A fan for life? Admap, pp. 25-27. Retrieved November 18, 2020, from http://www.warc.com/Content/LinkR esolver.aspx?

Tripathi,S.C.(2014).Women and criminal law.(2).Central Law Publications. New Delhi.

Teixeira, C. P., Spears, R., \& Yzerbyt, V. Y. (2019). Is Martin Luther king or Malcolm $X$ the more acceptable face of protest? High-status groups' reactions to lowstatus groups' collective action. Journal 
of Personality and Social Psychology, 118(5), 919-944 https://doi.org/10.1037/ pspi0000195.

Valenzuela, S. (2013). Unpacking the use of social media for protest behavior. American Behavioral Scientist, 57(7), 920-942. https://doi.org/10.1177/0002764213479 375.

Zarkov, D., \& Davis, K. (2018). Ambiguities and dilemmas around \#MeToo: \#for how long and \#whereto? European Journal of Women's Studies, 25(1), 3-9. https://doi.org/ 10.1177/1350506817749436. 